\title{
Pulmonary Alveolar Proteinosis
}

\author{
Ajmal Khan MD DM and Ritesh Agarwal MD DM
}

\author{
Introduction \\ Methods \\ Epidemiology \\ Normal Surfactant Physiology \\ Pathogenesis of Autoimmune Pulmonary Alveolar Proteinosis \\ Pathology \\ Classification \\ Clinical Features \\ Diagnosis \\ Radiology \\ High-Resolution Computed Tomography \\ Bronchoalveolar Lavage \\ Tissue Biopsy \\ Granulocyte Macrophage Colony Stimulating Factor Autoantibody \\ Severity Assessment \\ Pulmonary Function Tests \\ Gas Exchange \\ Granulocyte Macrophage Colony Stimulating Factor Autoantibody Titers \\ Biomarkers \\ Treatment \\ Whole-Lung Lavage \\ Exogenous Granulocyte Macrophage Colony Stimulating Factor Therapy \\ Novel Therapies \\ Summary
}

Pulmonary alveolar proteinosis is a rare but potentially treatable disease, characterized by impaired surfactant metabolism that leads to accumulation in the alveoli of proteinaceous material rich in surfactant protein and its component. Novel insights from an animal model aided the discovery of granulocyte macrophage colony stimulating factor (GM-CSF) antibodies as a pathogenetic mechanism in human pulmonary alveolar proteinosis. The vast majority of pulmonary alveolar proteinosis occurs as an autoimmune disease; less commonly, it is congenital or secondary to an underlying disorder such as infection, hematological malignancy, or immunodeficiency. The subacute indolent course of this disease often delays the diagnosis by months to years. Crazy-paving appearance in a geographic distribution is a characteristic feature of this disease visible on highresolution computed tomography (CT). A definitive diagnosis, however, requires lung biopsy, which typically shows partial or complete filling of alveoli with periodic-acid-Schiff-positive granular and eosinophilic material in preserved alveolar architecture. Patients with minimal symptoms are managed conservatively, whereas patients with hypoxemia require a more aggressive approach. Wholelung lavage is the most widely accepted therapy for symptomatic pulmonary alveolar proteinosis. Correction of GM-CSF deficiency with exogenous GM-CSF is an alternative therapy. The combination of a systemic treatment (GM-CSF) and a local treatment (whole-lung lavage) augmenting the 
action of one another is a promising new approach. As the knowledge about this rare disease increases, the role of novel therapies is likely to be better defined and optimized. Key words: pulmonary alveolar proteinosis; surfactant; alveoli; autoimmune disease. [Respir Care 2011;56(7):10161028. (C) 2011 Daedalus Enterprises]

\section{Introduction}

Pulmonary alveolar proteinosis, first described by Rosen et al in $1958,{ }^{1}$ is a rare pulmonary disease with a worldwide distribution. It is a syndrome of altered surfactant homeostasis, characterized by accumulation of periodicacid-Schiff-positive proteinaceous material in the alveoli. The resultant disturbance leads to clinical manifestation ranging from asymptomatic disease to life-threatening respiratory failure. ${ }^{2}$ New insights gained from knockout mice models, ${ }^{3-5}$ nonhuman primates, ${ }^{6,7}$ and granulocyte macrophage colony stimulating factor (GM-CSF) autoantibodies in human pulmonary alveolar proteinosis suggest a causal role of GM-CSF in the pathogenesis. ${ }^{89}$ Although ongoing studies are still evaluating its role, recent data suggest that exogenous GM-CSF therapy (to treat GM-CSF deficiency) has potential in the treatment of autoimmune pulmonary alveolar proteinosis. ${ }^{10}$ This review summarizes recent advances in pathogenesis and treatment of this rare but potentially treatable condition.

\section{Methods}

For this review we searched the PubMed and Embase databases for reports on the epidemiology, clinical presentation, evaluation, assessment, pathogenesis, and treatment of pulmonary alveolar proteinosis, published in English, up to August 2010. We used free terms, including "pulmonary alveolar proteinosis," alone and in combination with epidemiology, diagnosis, bronchoalveolar lavage, crazy paving, GM-CSF, autoimmune or idiopathic pulmonary alveolar proteinosis, and whole-lung lavage. We also reviewed the references of primary studies, reviews, case reports, and editorials. All the identified references were reviewed by one of us.

The authors are affiliated with the Department of Pulmonary Medicine, Postgraduate Institute of Medical Education and Research, Chandigarh, India.

The authors have disclosed no conflicts of interest.

Correspondence: Ritesh Agarwal MD DM, Department of Pulmonary Medicine, Postgraduate Institute of Medical Education and Research, Chandigarh 160012 India. E-mail: riteshpgi@gmail.com.

DOI: $10.4187 /$ respcare. 01125

\section{Epidemiology}

Because of the rarity of pulmonary alveolar proteinosis, it is difficult to estimate its true incidence and prevalence. Initial studies reported the prevalence of autoimmune pulmonary alveolar proteinosis at 3.7 cases per million; however, recent reports described a higher prevalence of about 6.2 cases per million. ${ }^{9}, 11,12$ That difference in prevalence estimates suggests that the disease has a geographical distribution, but more epidemiological data are required to confirm that suspicion.

In most reported series there has been a male preponderance, with a male-to-female ratio range of 2.1:1 to 2.7: $1 .{ }^{12}$ The usual duration of symptoms prior to diagnosis is around 7-10 months..$^{9,12,13}$ In a retrospective review of 410 cases, Seymour et al found a median age at diagnosis of 39 years, with the disease manifesting at a later age in the males. They also reported a bimodal pattern, with a peak age frequency in females of $25-40$ years. ${ }^{12}$ Similar age distribution and male preponderance was also reported from China in 281 patients. ${ }^{13}$ However, in 2 recent reports of 223 and 38 cases from Japan and Korea, respectively, the mean age at diagnosis was 51 and 52 years, with no sex difference. ${ }^{9,14}$ There was a significantly lower proportion of smokers $(57 \%)$ in the recent Asian report, than the previously reported prevalence of $72 \%$, which suggests that smoking is only casually associated and that other factors may be involved in the etiology. ${ }^{9,12}$

\section{Normal Surfactant Physiology}

Surfactant phospholipids are synthesized and stored as lamellar bodies in alveolar type II pneumocytes. Upon exocytosis into the alveolar lumen they interact with surfactant proteins and organize into tubular myelin that forms a mono-layer or multi-layer at the air-liquid interface, which reduces the surface tension and prevents alveolar collapse. ${ }^{15}$ Approximately $70-80 \%$ of the inactivated surfactant is taken up by alveolar type II cells for recycling or catabolism. The remaining surfactant is phagocytosed and degraded by alveolar macrophages or enters the lymphatic stream. ${ }^{2}$ Thus, a balanced production and catabolism tightly regulates the surfactant homeostasis. GM-CSF, which is present in serum and most tissues, binds to its receptors on monocytes, macrophages, and alveolar type II cells to initiate the biological effect. ${ }^{3,16,17}$ In the lungs, GM-CSF stimulates the terminal differentiation of alveolar macrophages 
mediated by transcription factor PU.1 to enhance their capacity for uptake and catabolism of surfactant proteins and surfactant phospholipids. ${ }^{18-20}$ In the presence of highaffinity neutralizing immunoglobulin $\mathrm{G}(\mathrm{IgG})$ antibodies against GM-CSF, alveolar macrophages lose their ability for adhesion, chemotaxis, microbicidal activity, phagocytosis, and phagolysosome fusion, leading to disruption of surfactant homeostasis and accumulation within the alveoli. ${ }^{21-24}$

\section{Pathogenesis of Autoimmune Pulmonary Alveolar Proteinosis}

New insights from ultrastructural, ${ }^{25}$ biochemical, ${ }^{26,27}$ and functional investigations of bronchoalveolar lavage fluid (BALF) indicate that abnormal clearance, rather than the excessive production, of surfactant is the key mechanism in the pathogenesis of pulmonary alveolar proteinosis. ${ }^{2,28}$ The seminal discovery that knockout mice deficient in GM-CSF or its receptor developed lung lesions similar to pulmonary alveolar proteinosis, and the reversal of those abnormalities with GM-CSF therapy, suggested a potential role for exogenous GM-CSF. ${ }^{4,5,29}$ However, the presence of a normal GM-CSF gene and functionally intact GMCSF receptor with downward signaling strongly argues against the role of absolute deficiency of GM-CSF as the pathogenetic mechanism in human pulmonary alveolar proteinosis. ${ }^{30,31}$ Subsequently, the discovery of systemic (serum) and local (BALF) neutralizing antibodies against GMCSF in idiopathic pulmonary alveolar proteinosis but not in healthy controls, resulting in a virtual deficiency of functional GM-CSF, suggested that the pathophysiological abnormality may originate from the generation of autoantibody against GM-CSF. ${ }^{8}$ The strong association of GMCSF antibodies in human autoimmune pulmonary alveolar proteinosis is further supported by the recent observation of pathology findings similar to human pulmonary alveolar proteinosis in nonhuman primates (Macaca fascicularis) after passively transferring highly purified GM-CSF autoantibodies from a patient with pulmonary alveolar proteinosis. ${ }^{6,7}$ Thus, the final common pathway appears to be the deficiency of functionally active GM-CSF. Additionally, the discovery of GM-CSF antibody in an indium tin oxide worker with pulmonary alveolar proteinosis raises the possible role of inhaled agents in the triggering and development of autoimmune pulmonary alveolar proteinosis, though this is speculative and needs confirmation. ${ }^{32}$

\section{Pathology}

The characteristic findings of pulmonary alveolar proteinosis on light microscopy in lung specimens include partial or complete filling of alveoli with diastase-resistant, periodic-acid-Schiff-positive, granular and eosino-

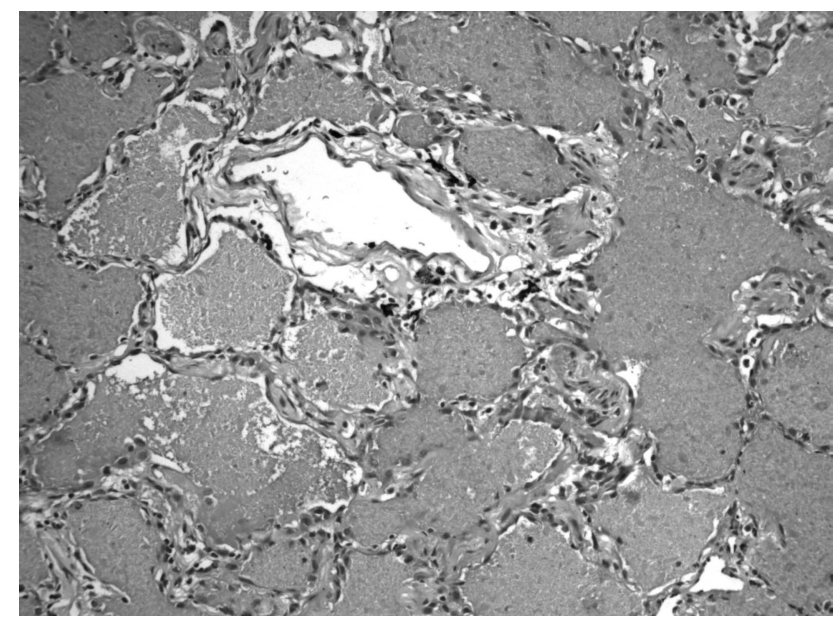

Fig. 1. Eosinophilic granular material filling alveolar spaces, with little reaction in alveolar walls (hematoxylin and eosin stain, magnification $\times 100$ ).

philic lipoproteinaceous material, and relatively preserved alveolar architecture (Fig. 1). ${ }^{1}$ Abnormally enlarged alveolar macrophages and intracellular accumulation of surfactant-like material are also present. Lymphocytic infiltration, fibroblasts, and fibrosis occur occasionally. With anti-surfactant protein A immunostain, substantial accumulation of surfactant protein can be seen in the alveoli. ${ }^{26}$ Electron microscopic ultrastructural examination of BALF sediment shows amorphous debris and concentrically laminated phospholipid lamellar bodies (Fig. 2). ${ }^{25,33-35}$

\section{Classification}

Pulmonary alveolar proteinosis is classified into 2 main types: congenital and acquired. The acquired form is subdivided into the autoimmune form and the secondary form (ie, due to an underlying disorder). Congenital pulmonary alveolar proteinosis occurs due to mutation in the SFTPB gene entailing a surfactant-protein-B deficiency, gene encoding for $\mathrm{ABC}$ transporter $\mathrm{A} 3$ and CSF2RB gene encoding GM-CSF receptor $\beta$ chain. ${ }^{36-38}$ The majority of congenital pulmonary alveolar proteinoses are transmitted in an autosomal recessive manner. ${ }^{36,39}$ They characteristically present with an acute onset of rapidly progressive respiratory distress immediately after birth.

The acquired form is the most common in previously healthy adults. Because of the presence of anti-GM-CSF antibodies, the term "autoimmune pulmonary alveolar proteinosis" has been proposed for the idiopathic variety, which constitutes more than $90 \%$ of all reported cases of pulmonary alveolar proteinosis..$^{8,9,12,21}$ Secondary pulmonary alveolar proteinosis is caused by underlying conditions that reduce the number of or functionally impair alveolar macrophages (Table 1). ${ }^{35,40-86}$ 


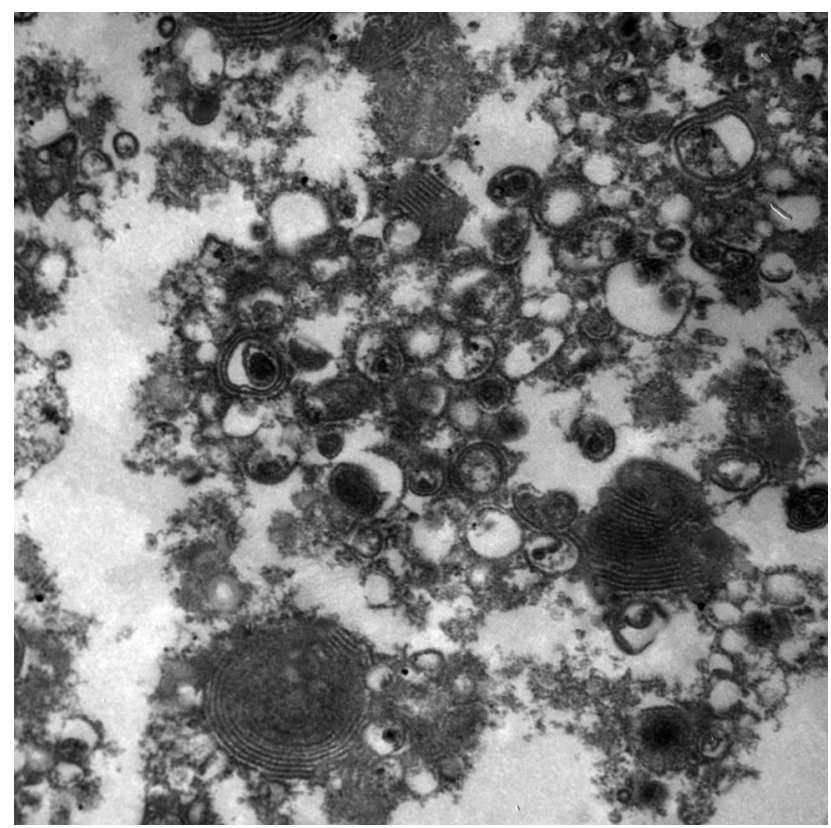

Fig. 2. Ultrastructural examination shows whorled lamellated surfactant bodies in the alveolar spaces (eosin-5-maleimide stain, magnification $\times 6450$ ).

\section{Clinical Features}

The onset of clinical disease is insidious, with a subacute indolent course that often delays the diagnosis by months to years. This delay is secondary to the time required for sufficient surfactant accumulation in the alveoli to impair gas exchange. Dyspnea, isolated or in combination with cough, occurs in a majority of the patients. Occasional patients may also have white and gummy sputum production, weight loss, hemoptysis, or fever. ${ }^{87,88}$ Physical examination is usually unremarkable, although there may be inspiratory crackles, clubbing, and cyanosis. ${ }^{89}$ Approximately $10-30 \%$ of patients are asymptomatic at presentation, ${ }^{9,14,90}$ whereas others present acutely with rapid progression to respiratory failure. ${ }^{91-95}$ Acute and rapid progression can occur because of infection. ${ }^{12}$ Pneumothorax and cor pulmonale occur rarely. ${ }^{96,97}$

\section{Diagnosis}

\section{Radiology}

Chest radiograph typically shows bilaterally symmetrical ill-defined nodular or confluent alveolar filling pattern, with a perihilar or basal distribution, ${ }^{98}$ but the radiographic pattern can also be asymmetric, ${ }^{99}$ unilateral, ${ }^{1,100}$ peripheral, or lobar. ${ }^{1}$ Absence of cardiomegaly, of pleural effusion, and extent of abnormality disproportionate to the
Table 1. Etiologies of Secondary Pulmonary Alveolar Proteinosis

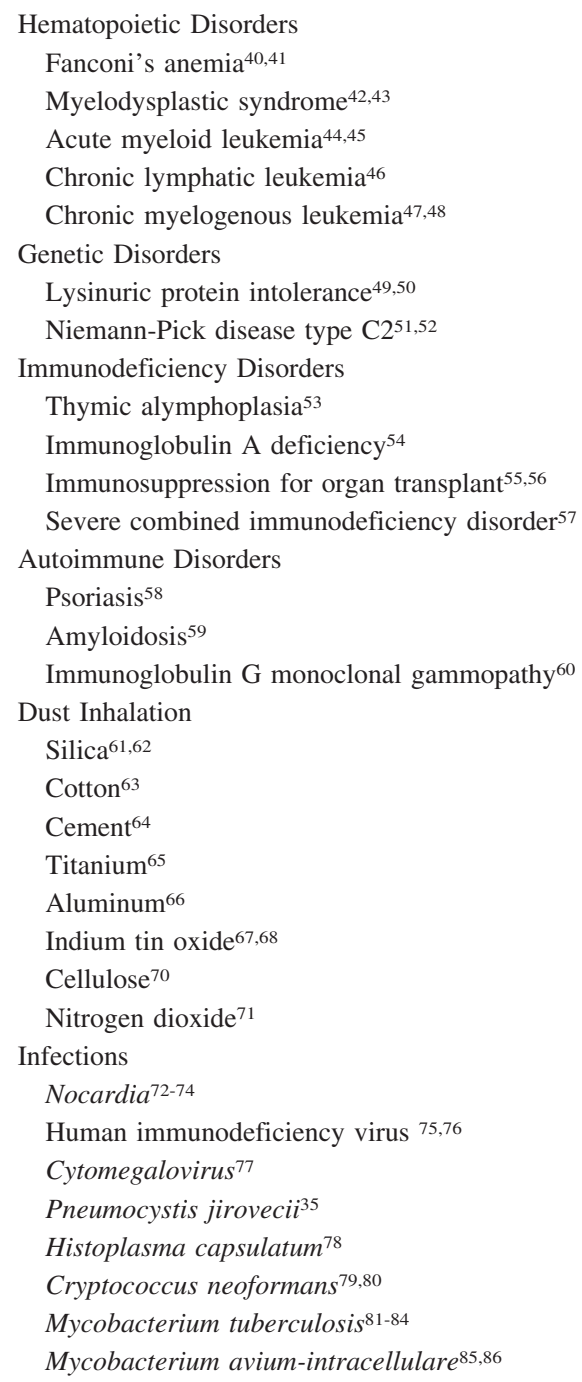

symptoms help exclude pulmonary edema, which is the most common cause of perihilar infiltrates.

\section{High-Resolution Computed Tomography}

High-resolution CT shows smooth inter-lobular and intra-lobular septal thickening superimposed on a background of ground-glass opacities, which produces the crazy-paving appearance that is characteristic of pulmonary alveolar proteinosis (Fig. 3). ${ }^{101,102}$ Accumulation of proteinaceous material in the air space adjacent to inter-lobular septa, and an interstitial fibrotic process, alone or in combination, have been proposed as a mechanism of crazy paving. ${ }^{103,104}$ The crazy-paving pattern is not pathognomonic of pulmonary alveolar proteinosis, and occurs in other infectious or non-infectious conditions. ${ }^{104-114}$ The subacute or chronic clinical course, absence of architectural distortion, smooth 


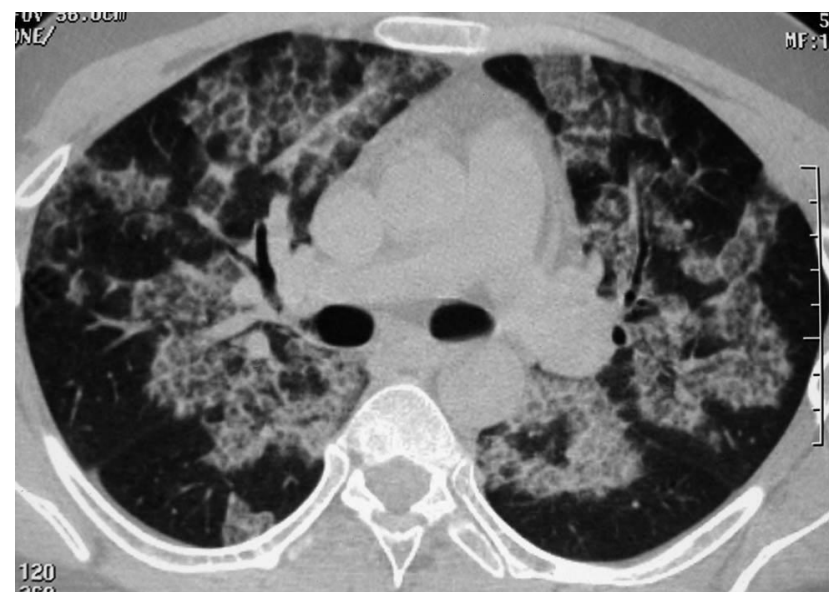

Fig. 3. High-resolution computed tomogram from a patient with pulmonary alveolar proteinosis demonstrates the characteristic crazy-paving appearance.

inter-lobular septal thickening, geographical distribution, and discordance between the clinical and radiological features help differentiate pulmonary alveolar proteinosis from other causes of crazy paving. In a study of 42 patients, Ishii et al ${ }^{115}$ reported differences in the pattern and distribution of ground-glass opacity on high-resolution CT, which help to differentiate secondary from autoimmune pulmonary alveolar proteinosis. They found a higher occurrence of basal distribution of ground-glass opacity and crazy paving in autoimmune pulmonary alveolar proteinosis; however, the ground-glass opacity tended to be patchy or geographic in autoimmune pulmonary alveolar proteinosis, in contrast to diffuse ground-glass opacity in the secondary variety. ${ }^{115}$ High-resolution CT is also useful to determine the extent of lung involvement and to assess the disease severity before treatment. ${ }^{102}$

\section{Bronchoalveolar Lavage}

BAL, with its characteristic appearance and ultrastructure, is helpful in the diagnosis. ${ }^{116,117}$ Grossly the BALF may be milky and opaque, and settles into a thick sediment layer and a translucent supernatant (Fig. 4). ${ }^{118}$ The BALF contains phospholipids and surfactant proteins $\mathrm{A}, \mathrm{B}$, and $\mathrm{D}$, and has relatively lower concentrations of phosphatidylcholine and phosphatidylglycerol. ${ }^{27,119,120}$ The most striking feature on microscopy is enlarged foamy alveolar macrophages engorged with diastase-resistant, periodicacid-Schiff-positive intracellular inclusions. ${ }^{121}$

On electron microscopy, abundant concentrically laminated structures called lamellar bodies are diagnostic of pulmonary alveolar proteinosis (see Fig. 2). ${ }^{25,122}$ On light microscopy, Papanicolaou stained BALF shows fat globules. ${ }^{116}$ In one study, a cutoff value of $>18$ fat globules per slide was highly suggestive of pulmonary alveolar pro-

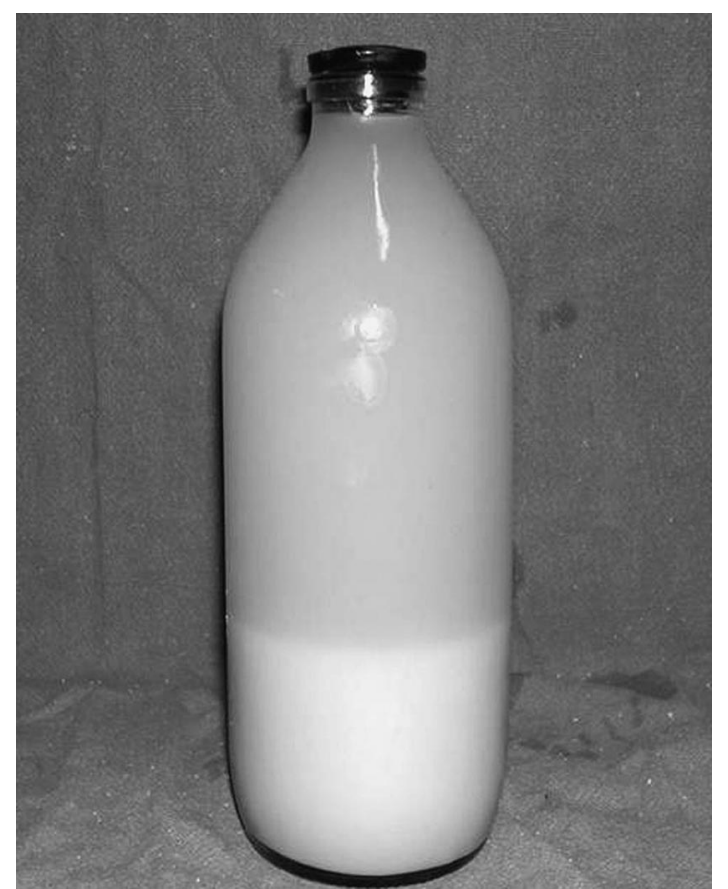

Fig. 4. Lung-lavage fluid from a patient with pulmonary alveolar proteinosis layers into a thick sediment and a translucent supernatant.

teinosis. ${ }^{123}$ A confident diagnosis of pulmonary alveolar proteinosis can be made with the combination of milky and opaque BALF and characteristic findings on highresolution CT. ${ }^{12}$ Tumor markers, mucin-like glycoprotein, and surfactant proteins also occur in the BALF, but their diagnostic utility is limited, as they are also present in other pulmonary diseases. ${ }^{124,125}$

\section{Tissue Biopsy}

The accepted standard for the diagnosis of pulmonary alveolar proteinosis is lung biopsy, via flexible bronchoscopy or surgery. ${ }^{1}$ Bronchoscopic biopsy can reliably establish the diagnosis and may obviate surgical lung biopsy, $, 987,88,90$ but, because of the patchy nature of the disease, a false negative result may be seen with bronchoscopic biopsy, with an additional risk of pneumothorax and hemorrhage. ${ }^{126}$

\section{Granulocyte Macrophage Colony Stimulating Factor Autoantibody}

GM-CSF autoantibodies are polyclonal and consist of $\operatorname{IgG} 1, \operatorname{IgG} 2$, and small amounts of $\operatorname{IgG} 3$ and $\operatorname{IgG} 4 .{ }^{127}$ Healthy individuals can have low levels of GM-CSF autoantibodies, but the risk of pulmonary alveolar proteinosis is increased if the GM-CSF antibody level is $>5 \mu \mathrm{g} /$ $\mathrm{mL} .^{7}$ The latex agglutination test is the most widely used 
test for the detection of GM-CSF antibodies. It has diagnostic sensitivity and specificity of $100 \%$ and $98 \%$, respectively, so it is the test of choice for autoimmune pulmonary alveolar proteinosis. ${ }^{128}$

\section{Severity Assessment}

The clinical course of pulmonary alveolar proteinosis ranges from stable disease with persistent symptoms to progressive deterioration, or, occasionally, spontaneous improvement. ${ }^{9,12,100,129}$ In addition to the subjective assessment of symptoms, pulmonary function tests, exercise capacity, gas exchange, and serum and bronchoalveolar biomarkers are used to assess disease severity and to guide management decisions.

\section{Pulmonary Function Tests}

The most common spirometric abnormality in pulmonary alveolar proteinosis is restrictive defect, manifested by decreased vital capacity and lung volume. ${ }^{9,12,13}$ Alveolar filling is reflected by a disproportionately reduced diffusing capacity for carbon monoxide. ${ }^{9,13}$ Following lung lavage these variables improve, which suggests a good correlation with the disease severity. ${ }^{129}$

\section{Gas Exchange}

Hypoxemia without abnormal arterial $\mathrm{pH}$ or $\mathrm{P}_{\mathrm{aCO}}$, and increased alveolar-arterial oxygen difference $\left(\mathrm{P}_{(\mathrm{A}-\mathrm{a}) \mathrm{O}_{2}}\right)$ that widens with exercise are prominent features of pulmonary alveolar proteinosis. ${ }^{9,12,129-131}$ These abnormalities occur due to intrapulmonary shunting of blood through poorly ventilated alveoli filled with proteinaceous material. ${ }^{130}$ Post-lavage improvement in these variables makes them convenient for monitoring the disease. ${ }^{129,130}$

\section{Granulocyte Macrophage Colony Stimulating Factor Autoantibody Titers}

Several initial reports suggested a relationship between serum anti-GM-CSF antibody titers and disease activity. ${ }^{132,133}$ Lin et al found a significant correlation between BALF (but not the serum GM-CSF antibodies) and other severity indicators, and subsequent requirement of therapeutic lung lavage. ${ }^{134}$ This could be related to compartmentalization leading to differences in BALF and serum antibody levels. Similarly, Seymour et al found no relationship between the serum anti-GM-CSF antibody concentration and disease severity or predicting the response to GM-CSF therapy. ${ }^{135}$ The neutralizing capacity of the antibody has been stated to be a more accurate marker of disease severity. ${ }^{136}$

\section{Biomarkers}

Abnormalities in the concentrations of proteins synthesized by the respiratory epithelium occur in pulmonary alveolar proteinosis, but their exact role in the severity assessment is uncertain. ${ }^{137}$ High levels of surfactant proteins, KL-6, and lactate dehydrogenase in serum and BALF have been described as evidence of severe disease. ${ }^{12,138-142}$ Several investigators have emphasized the value of these biomarkers in the diagnosis and severity assessment, ${ }^{27,142}$ but, due to their low specificity, they are seldom utilized. Similarly, tumor markers, such as squamous-cell carcinoma antigen, carcinoembryonic antigen, carbohydrate antigen 19-9, and cytokeratin 19 fragments, have been used in assessing pulmonary alveolar proteinosis. ${ }^{143,144}$ However, the clinical value of measuring these tumor markers in serum or BALF for diagnosis or severity assessment remains inconclusive. ${ }^{124}$

\section{Treatment}

The treatment of pulmonary alveolar proteinosis depends on the etiology (Fig. 5). Treatment of the congenital form depends on the patient's age at presentation, severity of symptoms, and anticipated disease course. In mild disease, supportive treatment may suffice. ${ }^{145}$ In severe disease, therapy may be individualized. Despite the technical difficulty, whole-lung lavage, ${ }^{146}$ lung transplantation, ${ }^{147,148}$ and heart and lung transplantation ${ }^{149}$ have been reported in congenital pulmonary alveolar proteinosis. The most effective treatment for secondary pulmonary alveolar proteinosis is treatment of the underlying condition. ${ }^{150}$

\section{Whole-Lung Lavage}

Whole-lung lavage has been the most widely accepted and effective therapy for more than 4 decades. Beginning with "segmental flooding" to physically remove the accumulated material, then extending the procedure to the first successful whole-lung lavage under local anesthesia, Ramirez et al revolutionized the concept of whole-lung lavage in pulmonary alveolar proteinosis. ${ }^{151,152}$ Over the years this original procedure has been refined and modified to achieve good results with less procedural difficulty and fewer complications..$^{95,126,153-172}$ The modifications include routine use of general anesthesia, ${ }^{153,154}$ larger lavage volume, ${ }^{154,155}$ lobar lavage, ${ }^{162}$ positional clearance, ${ }^{161}$ and chest percussion. ${ }^{159,161}$ Additionally, successful completion of bilateral sequential ${ }^{126}$ and simultaneous ${ }^{163}$ wholelung lavage in the same session has been achieved. Special circumstances such as advanced pulmonary alveolar proteinosis or cor pulmonale may dictate modification of the technique, including hyperbaric oxygen, ${ }^{158}$ inhaled nitric oxide, ${ }^{167,172}$ and extracorporeal membrane oxygenation. ${ }^{170}$ 


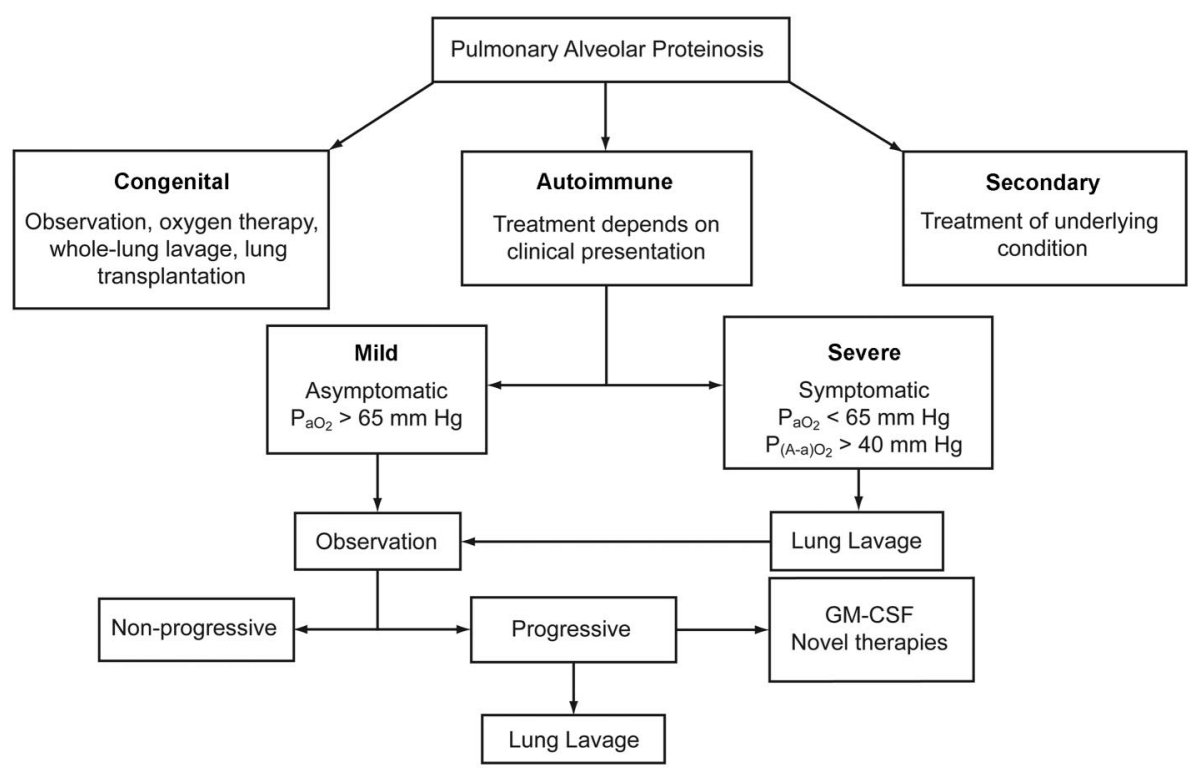

Fig. 5. Treatment algorithm for pulmonary alveolar proteinosis. $\mathrm{P}_{(\mathrm{A}-\mathrm{a}) \mathrm{O}_{2}}=$ alveolar-arterial oxygen difference. $\mathrm{GM}-\mathrm{CSF}=$ granulocyte macrophage colony stimulating factor.

In milder disease, lung lavage may be performed via flexible bronchoscopy in a conscious patient; however, the effectiveness of that procedure is unclear. ${ }^{173,175}$ Physical therapy (manual percussion, vibration, and chest compression) started during last the two thirds of infusion of saline and continuing till drainage can significantly increase the amount of material removed. ${ }^{159,174}$ Combination of physical therapy and gravity drainage optimizes the effective removal process. The benefits of whole-lung lavage are related to the physical removal of proteinaceous material and the local anti-GM-CSF antibodies, which restores the migration and phagocytic functions of alveolar macrophages. ${ }^{174-176}$

The major indication for and timing of whole-lung lavage is symptomatic disease with dyspnea that limits activity and progressive deterioration of arterial oxygenation. ${ }^{98}$ In some centers, $\mathrm{P}_{\mathrm{aO}_{2}}<65 \mathrm{~mm} \mathrm{Hg}, \mathrm{P}_{(\mathrm{A}-\mathrm{a}) \mathrm{O}_{2}}>40 \mathrm{~mm} \mathrm{Hg}$, or a shunt fraction $>10-12 \%$ are used as threshold values for therapeutic lung lavage. ${ }^{129,130}$ Clinical, ${ }^{129,130,177}$ functional, ${ }^{100,129,177}$ and radiological ${ }^{178}$ improvement are seen in approximately $80 \%$ of patients after the first whole-lung lavage, and the median duration of benefit can be as long as 15 months, but the majority require repeat lavage. ${ }^{12}$ Approximately 15\% require lavage every 6 months, and lack of response is reported in less than 10\%.126,130 Whole lung lavage provides only temporary symptom relief, without correcting the underlying defect, and has the additional disadvantage that it is a complex procedure that may require prolonged general anesthesia and has a risk of pneumonia, sepsis, acute respiratory distress syndrome, and pneumothorax. ${ }^{179-181}$ Despite these challenges, whole-lung lavage remains the therapy of choice and is associated with significantly better 5 -year survival, compared to those who do not receive lavage. ${ }^{12}$

\section{Exogenous Granulocyte Macrophage Colony Stimulating Factor Therapy}

Based on the pathophysiology of pulmonary alveolar proteinosis, treatment aimed at relieving functional GMCSF deficiency by administering exogenous GM-CSF or suppressing the neutralizing antibody has been utilized simultaneously or even as an alternate to whole-lung lavage. Several reports found favorable response with systemic (subcutaneous) or localized (aerosol) GMCSF. ${ }^{10,132,136,142,182-191}$ Prompt improvement with resumption of GM-CSF in patients who relapsed with GMCSF therapy suggests that disease resolution was not attributable to spontaneous remission and that GM-CSF does have therapeutic activity. ${ }^{183}$

Response is generally slow after GM-CSF therapy: the majority of patients show $\mathrm{P}_{(\mathrm{A}-\mathrm{a}) \mathrm{O}_{2}}$ improvement of $\geq 10 \mathrm{~mm} \mathrm{Hg}$ only after 4-6 weeks. ${ }^{181-190}$ Despite the slower improvement in oxygenation with GM-CSF, the magnitude of therapeutic effect achievable with GM-CSF or whole-lung lavage may be similar. ${ }^{184}$ The observed delay in response is due to the time required for immature precursor cells to be recruited to the lung and stimulated by GM-CSF to differentiate into functional alveolar macrophages. The predictors of response with GM-CSF are yet to be determined, but one study found pre-treatment variables such as longer time from diagnosis, higher vital capacity, normal serum lactate dehydrogenase level, and higher plasma surfactant-protein-B level to be significantly 
associated with response to GM-CSF. Similarly, peak eosinophil count following GM-CSF was the only treatmentrelated variable associated with response. ${ }^{184}$ GM-CSF is generally well tolerated, but flushing, tachycardia, hypotension, musculoskeletal pain, dyspnea, nausea and vomiting, rigors, involuntary leg spasms, and syncope may occur following the first dose. These symptoms usually last for $10 \mathrm{~min}$ and do not recur with subsequent doses. ${ }^{192}$ Currently, one open-label and one randomized trial of GMCSF in pulmonary alveolar proteinosis is underway, the results of which will clarify the future standard of therapy.

\section{Novel Therapies}

In patients who fail to respond to GM-CSF or wholelung lavage (or require repeated lavage), novel therapies have been tried. ${ }^{2,193}$

Plasmapheresis. Plasmapheresis to reduce the number of anti-GM-CSF antibodies and restore surfactant catabolism in alveolar macrophages is one novel approach. Plasmapheresis promptly improved symptoms, oxygen saturation, and radiographic appearance, with reduction in antibody titer, in one patient who was unresponsive to whole-lung lavage and subcutaneous GM-CSF. ${ }^{132}$ However, Luisetti et al found that lowering the GM-CSF level from $250 \mu \mathrm{g} / \mathrm{mL}$ to $156 \mu \mathrm{g} / \mathrm{mL}$ was not accompanied by clinical improvement after ten 1.5-L plasma exchanges in autoimmune pulmonary alveolar proteinosis with persistent disease, despite supplemental whole-lung lavage. They concluded that the small reduction in GM-CSF autoantibody level with plasmapheresis is not expected to have a therapeutic effect. ${ }^{194}$ Whether the combination of a systemic treatment (plasmapheresis) and a local treatment (whole-lung lavage) can act synergistically to lower the production of GM-CSF autoantibodies requires further evaluation.

Biological Therapies. Reducing autoantibody levels by depleting B lymphocyte is another novel approach. Rituximab, a monoclonal antibody directed against the CD20 antigen of B lymphocytes, has been tested. ${ }^{195,196}$ Although decrease in anti-GM-CSF activity was evident within 3 months of rituximab infusion, the clinical response was evident only after 9 months. ${ }^{195}$ The delayed response may be related to recruitment of functional macrophages to the alveoli to stimulate surfactant clearance.

Other Potential Therapies. There have also been reports of treatment with trypsin, chymotrypsin, ambroxol, antibiotics, IgG, and enzymatic debridement, but the clinical value of those therapies is unclear. ${ }^{197-203}$

\section{Summary}

In the appropriate clinical setting, with typical chest radiographic and high-resolution $\mathrm{CT}$ findings, a diagnosis of pulmonary alveolar proteinosis can be established with the help of anti-GM-CSF antibodies and/or BALF and transbronchial lung biopsy. In selected patients, however, open or video-assisted lung biopsy may be required. Asymptomatic patients can be observed with periodic assessment. Patients with milder symptoms can be offered GM-CSF therapy or combined bronchoscopic lung lavage and GM-CSF therapy. In severe cases, whole-lung lavage with a double-lumen endotracheal tube under general anesthesia is the therapy of choice. With advancement of our knowledge of this rare disease, the roles of alternative therapies are likely to be better defined and optimized.

\section{REFERENCES}

1. Rosen SH, Castleman B, Liebow AA. Pulmonary alveolar proteinosis. N Engl J Med 1958;258(23):1123-1142.

2. Trapnell BC, Whitsett JA, Nakata K. Pulmonary alveolar proteinosis. N Engl J Med 2003;349(26):2527-2539.

3. Burgess AW, Camakaris J, Metcalf D. Purification and properties of colony-stimulating factor from mouse lung-conditioned medium. J Biol Chem 1977;252(6):1998-2003.

4. Dranoff G, Crawford AD, Sadelain M, Ream B, Rashid A, Bronson $\mathrm{RT}$, et al. Involvement of granulocyte-macrophage colony-stimulating factor in pulmonary homeostasis. Science 1994;264(5159): 713-716.

5. Stanley E, Lieschke GJ, Grail D, Metcalf D, Hodgson G, Gall JA, et al. Granulocyte/macrophage colony-stimulating factor-deficient mice show no major perturbation of hematopoiesis but develop a characteristic pulmonary pathology. Proc Natl Acad Sci USA 1994; 91(12):5592-5596.

6. Sakagami T, Uchida K, Suzuki T, Carey BC, Wood RE, Wert SE, et al. Human GM-CSF autoantibodies and reproduction of pulmonary alveolar proteinosis. N Engl J Med 2009;361(27):2679-2681.

7. Sakagami T, Beck D, Uchida K, Suzuki T, Carey BC, Nakata K, et al. Patient-derived granulocyte/macrophage colony-stimulating factor autoantibodies reproduce pulmonary alveolar proteinosis in nonhuman primates. Am J Respir Crit Care Med 2010;182(1):49-61.

8. Kitamura T, Tanaka N, Watanabe J, Uchida, Kanegasaki S, Yamada $\mathrm{Y}$, et al. Idiopathic pulmonary alveolar proteinosis as an autoimmune disease with neutralizing antibody against granulocyte/macrophage colony-stimulating factor. J Exp Med 1999;190(6):875880.

9. Inoue Y, Trapnell BC, Tazawa R, Arai T, Takada T, Hizawa N, et al. Characteristics of a large cohort of patients with autoimmune pulmonary alveolar proteinosis in Japan. Am J Respir Crit Care Med 2008;177(7):752-762.

10. Seymour JF, Dunn AR, Vincent JM, Presneill JJ, Pain MC. Efficacy of granulocyte-macrophage colony-stimulating factor in acquired alveolar proteinosis. N Engl J Med 1996;335(25):1924-1925.

11. Ben-Dov I, Kishinevski Y, Roznman J, Soliman A, Bishara H, Zelligson E, et al. Pulmonary alveolar proteinosis in Israel: ethnic clustering. Isr Med Assoc J 1999;1(2):75-78.

12. Seymour JF, Presneill JJ. Pulmonary alveolar proteinosis: progress in the first 44 years. Am J Respir Crit Care Med 2002;166(2):215235 . 


\section{Pulmonary Alveolar Proteinosis}

13. Xu Z, Jing J, Wang H, Xu F, Wang J. Pulmonary alveolar proteinosis in China: a systematic review of 241 cases. Respirology 2009;14(5):761-766.

14. Byun MK, Kim DS, Kim YW, Chung MP, Shim JJ, Cha SI, et al. Clinical features and outcomes of idiopathic pulmonary alveolar proteinosis in Korean population. J Korean Med Sci 2010;25(3): 393-398.

15. Trapnell BC, Whitsett JA. Gm-CSF regulates pulmonary surfactant homeostasis and alveolar macrophage-mediated innate host defense. Annu Rev Physiol 2002;64:775-802.

16. Gearing DP, King JA, Gough NM, Nicola NA. Expression cloning of a receptor for human granulocyte-macrophage colony-stimulating factor. EMBO J 1989;8(12):3667-3676.

17. Hayashida K, Kitamura T, Gorman DM, Arai K, Yokota T, Miyajima A. Molecular cloning of a second subunit of the receptor for human granulocyte-macrophage colony-stimulating factor (GMCSF): reconstitution of a high-affinity GM-CSF receptor. Proc Natl Acad Sci USA 1990;87(24):9655-9659.

18. Bonfield TL, Raychaudhuri B, Malur A, Abraham S, Trapnell BC, Kavuru MS, et al. PU. 1 regulation of human alveolar macrophage differentiation requires granulocyte-macrophage colony-stimulating factor. Am J Physiol Lung Cell Mol Physiol 2003;285(5):L1132-1136.

19. Akagawa KS, Kamoshita K, Tokunaga T. Effects of granulocytemacrophage colony-stimulating factor and colony-stimulating factor- 1 on the proliferation and differentiation of murine alveolar macrophages. J Immunol 1988;141(10):3383-3390.

20. Chen BD, Mueller M, Chou TH. Role of granulocyte/macrophage colony-stimulating factor in the regulation of murine alveolar macrophage proliferation and differentiation. J Immunol 1988;141(1): $139-144$

21. Uchida K, Nakata K, Trapnell BC, Terakawa T, Hamano E, Mikami A, et al. High-affinity autoantibodies specifically eliminate granulocyte-macrophage colony-stimulating factor activity in the lungs of patients with idiopathic pulmonary alveolar proteinosis. Blood 2004;103(3):1089-1098.

22. Golde DW, Territo M, Finley TN, Cline MJ. Defective lung macrophages in pulmonary alveolar proteinosis. Ann Intern Med 1976; 85(3):304-309.

23. Harris JO. Pulmonary alveolar proteinosis: abnormal in vitro function of alveolar macrophages. Chest 1979;76(2):156-159.

24. Gonzalez-Rothi RJ, Harris JO. Pulmonary alveolar proteinosis. Further evaluation of abnormal alveolar macrophages. Chest 1986; 90(5):656-661.

25. Costello JF, Moriarty DC, Branthwaite MA, Turner-Warwick M, Corrin B. Diagnosis and management of alveolar proteinosis: the role of electron microscopy. Thorax 1975;30(2):121-132.

26. Singh G, Katyal SL, Bedrossian CW, Rogers RM. Pulmonary alveolar proteinosis. Staining for surfactant apoprotein in alveolar proteinosis and in conditions simulating it. Chest 1983;83(1):82-86.

27. Honda Y, Takahashi H, Shijubo N, Kuroki Y, Akino T. Surfactant protein-A concentration in bronchoalveolar lavage fluids of patients with pulmonary alveolar proteinosis. Chest 1993;103(2):496-499.

28. Ramirez J, Harlan WR Jr. Pulmonary alveolar proteinosis: nature and origin of alveolar lipid. Am J Med 1968;45(4):502-512.

29. Reed JA, Ikegami M, Cianciolo ER, Lu W, Cho PS, Hull W, et al. Aerosolized GM-CSF ameliorates pulmonary alveolar proteinosis in GM-CSF-deficient mice. Am J Physiol 1999;276(4 Pt 1):L556563.

30. Thomassen MJ, Yi T, Raychaudhuri B, Malur A, Kavuru MS. Pulmonary alveolar proteinosis is a disease of decreased availability of GM-CSF rather than an intrinsic cellular defect. Clin Immunol 2000;95(2):85-92.

31. Carraway MS, Ghio AJ, Carter JD, Piantadosi CA. Detection of granulocyte-macrophage colony-stimulating factor in patients with pulmonary alveolar proteinosis. Am J Respir Crit Care Med 2000; 161(4 Pt 1):1294-1299.

32. Costabel U, Nakata K. Pulmonary alveolar proteinosis associated with dust inhalation: not secondary but autoimmune? Am J Respir Crit Care Med 2010;181(5):427-428.

33. Gilmore LB, Talley FA, Hook GE. Classification and morphometric quantitation of insoluble materials from the lungs of patients with alveolar proteinosis. Am J Pathol 1988;133(2):252-264.

34. Verbeken EK, Demedts M, Vanwing J, Deneffe G, Lauweryns JM. Pulmonary phospholipid accumulation distal to an obstructed bronchus: a morphologic study. Arch Pathol Lab Med 1989;113(8):886890.

35. Tran Van Nhieu J, Vojtek AM, Bernaudin JF, Escudier E, FleuryFeith J. Pulmonary alveolar proteinosis associated with Pneumocystis carinii: ultrastructural identification in bronchoalveolar lavage in AIDS and immunocompromised non-AIDS patients. Chest 1990;98(4):801-805.

36. Nogee LM, de Mello DE, Dehner LP, Colten HR. Brief report: deficiency of pulmonary surfactant protein B in congenital alveolar proteinosis. N Engl J Med 1993;328(6):406-410.

37. Dirksen U, Hattenhorst U, Schneider P, Schroten H, Gobel U, Bocking A, et al. Defective expression of granulocyte-macrophage colony-stimulating factor/interleukin-3/interleukin-5 receptor common beta chain in children with acute myeloid leukemia associated with respiratory failure. Blood 1998;92(4):1097-1103.

38. Shulenin S, Nogee LM, Annilo T, Wert SE, Whitsett JA, Dean M. ABCA3 gene mutations in newborns with fatal surfactant deficiency. N Engl J Med 2004;350(13):1296-1303.

39. Teja K, Cooper PH, Squires JE, Schnatterly PT. Pulmonary alveolar proteinosis in four siblings. N Engl J Med 1981;305(23):13901392.

40. Eldar M, Shoenfeld Y, Zaizov R, Fogel R, Asherov J, Liban E, et al. Pulmonary alveolar proteinosis associated with fanconi's anemia. Respiration 1979;38(3):177-179.

41. Dirksen U, Moritz T, Burdach S, Flasshove M, Hanenberg H. Fanconi anemia and beta c deficiency-associated pulmonary alveolar proteinosis as two hereditary diseases of childhood which are potentially curable by stem cell gene therapy but require different therapeutic approaches. Klin Padiatr 1999;211(4):329-335.

42. Ohnishi T, Yamada G, Shijubo N, Takagi-Takahashi Y, Itoh T, Takahashi $\mathrm{H}$, et al. Secondary pulmonary alveolar proteinosis associated with myelodysplastic syndrome. Intern Med 2003;42(2): 187-190.

43. Kajiume T, Yoshimi S, Nagita A, Kobayashi K, Kataoka N, Nakajima M, et al. A case of myelodysplastic syndrome complicated by pulmonary alveolar proteinosis with a high serum KL-6 level. Pediatr Hematol Oncol 1999;16(4):367-371.

44. Birsak CA, van Rossem RN, Nijhuis-Heddes JM, Maartense E. Pulmonary alveolar proteinosis: a complication in patients with hematologic malignancy. Neth J Med 2000;56(5):193-197.

45. Du EZ, Yung GL, Le DT, Masliah E, Yi ES, Friedman PJ. Severe alveolar proteinosis following chemotherapy for acute myeloid leukemia in a lung allograft recipient. J Thorac Imaging 2001;16(4): 307-309.

46. Breslow A, Snow P, Rosenberg MH. Pulmonary Alveolar Proteinosis and Chronic Lymphatic Leukemia Med Ann Dist Columbia 1965;34:209-212.

47. Aymard JP, Gyger M, Lavallee R, Legresley LP, Desy M. A case of pulmonary alveolar proteinosis complicating chronic myelogenous leukemia: a peculiar pathologic aspect of busulfan lung? Cancer 1984;53(4):954-956.

48. Cheng SL, Kuo PH, Yang PC, Luh KT. Bilateral alveolar infiltrates in a 29-year-old man with chronic myelogenous leukemia. Chest 2002;122(6):2238-2241. 


\section{Pulmonary Alveolar Proteinosis}

49. Ceruti M, Rodi G, Stella GM, Adami A, Bolongaro A, Baritussio A, et al. Successful whole lung lavage in pulmonary alveolar proteinosis secondary to lysinuric protein intolerance: a case report. Orphanet J Rare Dis 2007;2:14.

50. Santamaria F, Brancaccio G, Parenti G, Francalanci P, Squitieri C, Sebastio G, et al. Recurrent fatal pulmonary alveolar proteinosis after heart-lung transplantation in a child with lysinuric protein intolerance. J Pediatr 2004;145(2):268-272.

51. Bjurulf B, Spetalen S, Erichsen A, Vanier MT, Strom EH, Stromme $\mathrm{P}$. Niemann-Pick disease type $\mathrm{C} 2$ presenting as fatal pulmonary alveolar lipoproteinosis: morphological findings in lung and nervous tissue. Med Sci Monit 2008;14(8):CS71-CS75.

52. Griese M, Brasch F, Aldana VR, Cabrera MM, Goelnitz U, Ikonen E, et al. Respiratory disease in Niemann-Pick type $\mathrm{C} 2$ is caused by pulmonary alveolar proteinosis. Clin Genet 2010;77(2):119-130.

53. Haworth JC, Hoogstraten J, Taylor H. Thymic alymphoplasia. Arch Dis Child 1967;42(221):40-54.

54. Webster JR, Jr., Battifora H, Furey C, Harrison RA, Shapiro B. Pulmonary alveolar proteinosis in two siblings with decreased immunoglobulin A. Am J Med 1980;69(5):786-789.

55. Vethanayagam D, Pugsley S, Dunn EJ, Russell D, Kay JM, Allen C. Exogenous lipid pneumonia related to smoking weed oil following cadaveric renal transplantation. Can Respir J 2000;7(4):338342.

56. Yousem SA. Alveolar lipoproteinosis in lung allograft recipients. Hum Pathol 1997;28(12):1383-1386.

57. Fisher M, Roggli V, Merten D, Mulvihill D, Spock A. Coexisting endogenous lipoid pneumonia, cholesterol granulomas, and pulmonary alveolar proteinosis in a pediatric population: a clinical, radiographic, and pathologic correlation. Pediatr Pathol 1992;12(3): 365-383.

58. Steens RD, Summers QA, Tarala RA. Pulmonary alveolar proteinosis in association with Fanconi's anemia and psoriasis: a possible common pathogenetic mechanism. Chest 1992;102(2):637-638.

59. Merino-Angulo A, Perez-Marti M, Diaz de Otazu R. Pulmonary alveolar phospholipoproteinosis associated with amyloidosis. Chest 1990;98(4):1048.

60. Mork JN, Johnson JR, Zinneman HH, Bjorgen J. Pulmonary alveolar proteinosis associated with IgG monoclonal gammopathy. Arch Intern Med 1968;121(3):278-283.

61. Buechner HA, Ansari A. Acute silico-proteinosis: a new pathologic variant of acute silicosis in sandblasters, characterized by histologic features resembling alveolar proteinosis. Dis Chest 1969;55(4):274278.

62. Xipell JM, Ham KN, Price CG, Thomas DP. Acute silicoproteinosis. Thorax 1977;32(1):104-111.

63. Thind GS. Acute pulmonary alveolar proteinosis due to exposure to cotton dust. Lung India 2009;26(4):152-154.

64. McCunney RJ, Godefroi R. Pulmonary alveolar proteinosis and cement dust: a case report. J Occup Med 1989;31(3):233-237.

65. Keller CA, Frost A, Cagle PT, Abraham JL. Pulmonary alveolar proteinosis in a painter with elevated pulmonary concentrations of titanium. Chest 1995;108(1):277-280.

66. Miller RR, Churg AM, Hutcheon M, Lom S. Pulmonary alveolar proteinosis and aluminum dust exposure. Am Rev Respir Dis 1984; 130(2):312-315.

67. Cummings KJ, Donat WE, Ettensohn DB, Roggli VL, Ingram P, Kreiss K. Pulmonary alveolar proteinosis in workers at an indium processing facility. Am J Respir Crit Care Med 2010;181(5):458464.

68. Xiao YL, Cai HR, Wang YH, Meng FQ, Zhang DP. Pulmonary alveolar proteinosis in an indium-processing worker. Chin Med J (Engl) 2010;123(10):1347-1350.
69. Ballantyne B. Pulmonary alveolar phospholipoproteinosis induced by Orasol Navy Blue dust. Hum Exp Toxicol 1994;13(10):694-699.

70. McDonald JW, Alvarez F, Keller CA. Pulmonary alveolar proteinosis in association with household exposure to fibrous insulation material. Chest 2000;117(6):1813-1817.

71. Dawkins SA, Gerhard H, Nevin M. Pulmonary alveolar proteinosis: a possible sequel of $\mathrm{NO}_{2}$ exposure. J Occup Med 1991;33(5):638641.

72. Burbank B, Morrione TG, Cutler SS. Pulmonary alveolar proteinosis and nocardiosis. Am J Med 1960;28:1002-1007.

73. Martinez-Maldonado M, Ramirez de Arellano G. Pulmonary alveolar proteinosis, nocardiosis and chronic granulocytic leukemia. South Med J 1966;59(8):901-905.

74. Pascual J, Gomez Aguinaga MA, Vidal R, Maudes A, Sureda A, Gomez Mampaso E, et al. Alveolar proteinosis and nocardiosis: a patient treated by bronchopulmonary lavage. Postgrad Med J 1989; 65(767):674-677.

75. Ruben FL, Talamo TS. Secondary pulmonary alveolar proteinosis occurring in two patients with acquired immune deficiency syndrome. Am J Med 1986;80(6):1187-1190.

76. Nachajon RV, Rutstein RM, Rudy BJ, Collins MH. Pulmonary alveolar proteinosis in an HIV-infected child. Pediatr Pulmonol 1997;24(4):292-295.

77. Ranchod M, Bissell M. Pulmonary alveolar proteinosis and cytomegalovirus infection. Arch Pathol Lab Med 1979;103(3):139-142.

78. Hartung M, Salfelder K. Pulmonary alveolar proteinosis and histoplasmosis: report of three cases. Virchows Arch A Pathol Anat Histol 1975;368(4):281-287.

79. Sunderland WA, Campbell RA, Edwards MJ. Pulmonary alveolar proteinosis and pulmonary cryptococcosis in an adolescent boy. J Pediatr 1972;80(3):450-456.

80. Bergman F, Linell F. Cryptococcosis as a cause of pulmonary alveolar proteinosis. Acta Pathol Microbiol Scand 1961;53:217-224.

81. Lathan SR Jr, Williams JD Jr, McLean RL, Ramirez J. Pulmonary alveolar proteinosis: treatment of a case complicated by tuberculosis. Chest 1971;59(4):452-454.

82. Pereira-Silva JL, Marinho MM, Veloso TV, Coelho JJ. Pulmonary alveolar proteinosis and tuberculosis in a diabetic patient: a rare or a seldom-diagnosed association? Braz J Infect Dis 2002;6(4):188-195.

83. Steer A. Focal pulmonary alveolar proteinosis in pulmonary tuberculosis. Arch Pathol 1969;87(3):347-352.

84. Reyes JM, Putong PB. Association of pulmonary alveolar lipoproteinosis with mycobacterial infection. Am J Clin Pathol 1980;74(4): 478-485.

85. Witty LA, Tapson VF, Piantadosi CA. Isolation of mycobacteria in patients with pulmonary alveolar proteinosis. Medicine (Baltimore) 1994;73(2):103-109.

86. Bakhos R, Gattuso P, Arcot C, Reddy VB. Pulmonary alveolar proteinosis: an unusual association with Mycobacterium avium-intracellulare infection and lymphocytic interstitial pneumonia. South Med J 1996;89(8):801-802.

87. Goldstein LS, Kavuru MS, Curtis-McCarthy P, Christie HA, Farver C, Stoller JK. Pulmonary alveolar proteinosis: clinical features and outcomes. Chest 1998;114(5):1357-1362.

88. Rubinstein I, Mullen JB, Hoffstein V. Morphologic diagnosis of idiopathic pulmonary alveolar lipoproteinosis-revisited. Arch Intern Med 1988;148(4):813-816.

89. Mazzone P, Thomassen MJ, Kavuru M. Our new understanding of pulmonary alveolar proteinosis: what an internist needs to know. Cleve Clin J Med 2001;68(12):977-978.

90. Asamoto H, Kitaichi M, Nishimura K, Itoh H, Izumi T. [Primary pulmonary alveolar proteinosis: clinical observation of 68 patients in Japan]. Jpn J Thorac Dis 1995;33(8):835-845. Article in Japanese. 
91. Cordonnier C, Fleury-Feith J, Escudier E, Atassi K, Bernaudin JF. Secondary alveolar proteinosis is a reversible cause of respiratory failure in leukemic patients. Am J Respir Crit Care Med 1994;149(3 Pt 1):788-794.

92. Dahmash NS, Al-Majed S, Sassi M. Fulminant respiratory failure secondary to alveolar proteinosis. Ann Saudi Med 1993;13(4):375377.

93. Dexter ME, Cosgrove GP, Douglas IS. Managing a rare condition presenting with intractable hypoxemic respiratory failure. Chest 2007;131(1):320-327.

94. Gacouin A, Le Tulzo Y, Suprin E, Briens E, Bernard M, Camus C, et al. Acute respiratory failure caused by secondary alveolar proteinosis in a patient with acute myeloid leukemia: a case report. Intensive Care Med 1998;24(3):265-267.

95. Cohen ES, Elpern E, Silver MR. Pulmonary alveolar proteinosis causing severe hypoxemic respiratory failure treated with sequential whole-lung lavage utilizing venovenous extracorporeal membrane oxygenation: a case report and review. Chest 2001;120(3): 1024-1026.

96. Anton HC, Gray B. Pulmonary alveolar proteinosis presenting with pneumothorax. Clin Radiol 1967;18(4):428-431.

97. Oliva PB, Vogel JH. Reactive pulmonary hypertension in alveolar proteinosis. Chest 1970;58(2):167-168.

98. Selecky PA, Wasserman K, Benfield JR, Lippmann M. The clinical and physiological effect of whole-lung lavage in pulmonary alveolar proteinosis: a ten-year experience. Ann Thorac Surg 1977; 24(5):451-461.

99. Rubin E, Weisbrod GL, Sanders DE. Pulmonary alveolar proteinosis: relationship to silicosis and pulmonary infection. Radiology 1980;135(1):35-41.

100. Prakash UB, Barham SS, Carpenter HA, Dines DE, Marsh HM. Pulmonary alveolar phospholipoproteinosis: experience with 34 cases and a review. Mayo Clin Proc 1987;62(6):499-518.

101. Holbert JM, Costello P, Li W, Hoffman RM, Rogers RM. CT features of pulmonary alveolar proteinosis. AJR 2001;176(5):12871294.

102. Lee KN, Levin DL, Webb WR, Chen D, Storto ML, Golden JA. Pulmonary alveolar proteinosis: high-resolution CT, chest radiographic, and functional correlations. Chest 1997;111(4):989-995.

103. Kang EY, Grenier P, Laurent F, Muller NL. Interlobular septal thickening: patterns at high-resolution computed tomography. J Thorac Imaging 1996;11(4):260-264.

104. Johkoh T, Itoh H, Muller NL, Ichikado K, Nakamura H, Ikezoe J, et al. Crazy-paving appearance at thin-section CT: spectrum of disease and pathologic findings. Radiology 1999;211(1):155-160.

105. Murayama S, Murakami J, Yabuuchi H, Soeda H, Masuda K. "Crazy paving appearance" on high resolution CT in various diseases. J Comput Assist Tomogr 1999;23(5):749-752.

106. Matsuno O, Hayama Y, Honda H, Yamane H, Yamamoto S, Ueno K, et al. Crazy-paving sign in high-resolution computed tomography in parainfluenza virus pneumonia. Radiography 2010;16:160-162.

107. Marchiori E, Gasparetto TD, Escuissato DL, Zanetti G. Leptospirosis of the lung presenting with crazy-paving pattern: correlation between the high-resolution CT and pathological findings. Rev Port Pneumol 2008;14(6):887-891.

108. Hisada T, Ishizuka T, Tomizawa Y, Iwasaki Y, Kawata T, Dobashi $\mathrm{K}$, et al. "Crazy-paving" appearance in systemic lupus erythematosus. Intern Med 2006;45(1):29-30.

109. Coche E, Weynand B, Noirhomme P, Pieters T. Non-specific interstitial pneumonia showing a "crazy paving" pattern on high resolution CT. Br J Radiol 2001;74(878):189-191.

110. Muller NL, Staples CA, Miller RR. Bronchiolitis obliterans organizing pneumonia: CT features in 14 patients. Am J Roentgenol 1990;154(5):983-987.
111. Franquet T, Gimenez A, Bordes R, Rodriguez-Arias JM, Castella J. The crazy-paving pattern in exogenous lipoid pneumonia: CT-pathologic correlation. AJR Am J Roentgenol 1998;170(2):315-317.

112. Marchiori E, Zanetti G, Mano CM, Irion KL, Daltro PA, Hochhegger B. Lipoid pneumonia in 53 patients after aspiration of mineral oil: comparison of high-resolution computed tomography findings in adults and children. J Comput Assist Tomogr 2010;34(1):9-12.

113. Tan RT, Kuzo RS. High-resolution CT findings of mucinous bronchioloalveolar carcinoma: a case of pseudopulmonary alveolar proteinosis. AJR Am J Roentgenol 1997;168(1):99-100.

114. Kim KI, Lee KN, Tomiyama N, Johkoh T, Ichikado K, Kim CW, et al. Near drowning: thin-section CT findings in six patients. J Comput Assist Tomogr 2000;24(4):562-566.

115. Ishii H, Trapnell BC, Tazawa R, Inoue Y, Akira M, Kogure Y, et al. Comparative study of high-resolution $\mathrm{CT}$ findings between autoimmune and secondary pulmonary alveolar proteinosis. Chest 2009;136(5):1348-1355.

116. Mikami T, Yamamoto Y, Yokoyama M, Okayasu I. Pulmonary alveolar proteinosis: diagnosis using routinely processed smears of bronchoalveolar lavage fluid. J Clin Pathol 1997;50(12):981-984.

117. Burkhalter A, Silverman JF, Hopkins MB 3rd, Geisinger KR. Bronchoalveolar lavage cytology in pulmonary alveolar proteinosis. Am J Clin Pathol 1996;106(4):504-510.

118. Martin RJ, Coalson JJ, Rogers RM, Horton FO, Manous LE. Pulmonary alveolar proteinosis: the diagnosis by segmental lavage. Am Rev Respir Dis 1980;121(5):819-825.

119. Crouch E, Persson A, Chang D. Accumulation of surfactant protein D in human pulmonary alveolar proteinosis. Am J Pathol 1993; 142(1):241-248.

120. Honda Y, Kataoka K, Hayashi H, Takahashi H, Suzuki A, Akino T. Alterations of acidic phospholipids in bronchoalveolar lavage fluids of patients with pulmonary alveolar proteinosis. Clin Chim Acta 1989;181(1):11-18.

121. Maygarden SJ, Iacocca MV, Funkhouser WK, Novotny DB. Pulmonary alveolar proteinosis: a spectrum of cytologic, histochemical, and ultrastructural findings in bronchoalveolar lavage fluid. Diagn Cytopathol 2001;24(6):389-395.

122. Hook GE, Gilmore LB, Talley FA. Multilamelled structures from the lungs of patients with pulmonary alveolar proteinosis. Lab Invest 1984;50(6):711-725.

123. Chou CW, Lin FC, Tung SM, Liou RD, Chang SC. Diagnosis of pulmonary alveolar proteinosis: usefulness of papanicolaou-stained smears of bronchoalveolar lavage fluid. Arch Intern Med 2001; 161(4):562-566.

124. Hirakata Y, Kobayashi J, Sugama Y, Kitamura S. Elevation of tumour markers in serum and bronchoalveolar lavage fluid in pulmonary alveolar proteinosis. Eur Respir J 1995;8(5):689-696.

125. Wang BM, Stern EJ, Schmidt RA, Pierson DJ. Diagnosing pulmonary alveolar proteinosis: a review and an update. Chest 1997; 111(2):460-466.

126. Shah PL, Hansell D, Lawson PR, Reid KB, Morgan C. Pulmonary alveolar proteinosis: clinical aspects and current concepts on pathogenesis. Thorax 2000;55(1):67-77.

127. Uchida K, Nakata K, Suzuki T, Luisetti M, Watanabe M, Koch DE, et al. Granulocyte/macrophage-colony-stimulating factor autoantibodies and myeloid cell immune functions in healthy subjects. Blood 2009;113(11):2547-2556.

128. Kitamura T, Uchida K, Tanaka N, Tsuchiya T, Watanabe J, Yamada $\mathrm{Y}$, et al. Serological diagnosis of idiopathic pulmonary alveolar proteinosis. Am J Respir Crit Care Med 2000;162(2 Pt 1):658-662.

129. Kariman K, Kylstra JA, Spock A. Pulmonary alveolar proteinosis: prospective clinical experience in 23 patients for 15 years. Lung 1984;162(4):223-231. 
130. Rogers RM, Levin DC, Gray BA, Moseley LW Jr. Physiologic effects of bronchopulmonary lavage in alveolar proteinosis. Am Rev Respir Dis 1978;118(2):255-264.

131. Inoue Y, Nakata K, Arai T, Tazawa R, Hamano E, Nukiwa T, et al. Epidemiological and clinical features of idiopathic pulmonary alveolar proteinosis in Japan. Respirology 2006;11(Suppl):S55-S60.

132. Bonfield TL, Kavuru MS, Thomassen MJ. Anti-GM-CSF titer predicts response to GM-CSF therapy in pulmonary alveolar proteinosis. Clin Immunol 2002;105(3):342-350.

133. Tazawa R, Hamano E, Arai $\mathrm{T}$, Ohta $\mathrm{H}$, Ishimoto $\mathrm{O}$, Uchida $\mathrm{K}$, et al. Granulocyte-macrophage colony-stimulating factor and lung immunity in pulmonary alveolar proteinosis. Am J Respir Crit Care Med 2005;171(10):1142-1149.

134. Lin FC, Chang GD, Chern MS, Chen YC, Chang SC. Clinical significance of anti-GM-CSF antibodies in idiopathic pulmonary alveolar proteinosis. Thorax 2006;61(6):528-534.

135. Seymour JF, Doyle IR, Nakata K, Presneill JJ, Schoch OD, Hamano E, et al. Relationship of anti-GM-CSF antibody concentration, surfactant protein A and B levels, and serum LDH to pulmonary parameters and response to GM-CSF therapy in patients with idiopathic alveolar proteinosis. Thorax 2003;58(3):252-257.

136. Arai T, Hamano E, Inoue Y, Ryushi T, Nukiwa T, Sakatani M, et al. Serum neutralizing capacity of GM-CSF reflects disease severity in a patient with pulmonary alveolar proteinosis successfully treated with inhaled GM-CSF. Respir Med 2004;98(12):1227-1230.

137. Hermans $C$, Bernard A. Lung epithelium-specific proteins: characteristics and potential applications as markers. Am J Respir Crit Care Med 1999;159(2):646-678.

138. Honda Y, Kuroki Y, Matsuura E, Nagae H, Takahashi H, Akino T, et al. Pulmonary surfactant protein $\mathrm{D}$ in sera and bronchoalveolar lavage fluids. Am J Respir Crit Care Med 1995;152(6 Pt 1):1860-1866.

139. Kuroki Y, Tsutahara S, Shijubo N, Takahashi H, Shiratori M, Hattori A, et al. Elevated levels of lung surfactant protein A in sera from patients with idiopathic pulmonary fibrosis and pulmonary alveolar proteinosis. Am Rev Respir Dis 1993;147(3):723-729.

140. Lin FC, Chen YC, Chang SC. Clinical importance of bronchoalveolar lavage fluid and blood cytokines, surfactant protein D, and Kerbs von Lungren 6 antigen in idiopathic pulmonary alveolar proteinosis. Mayo Clin Proc 2008;83(12):1344-1349.

141. Takahashi T, Munakata M, Suzuki I, Kawakami Y. Serum and bronchoalveolar fluid KL-6 levels in patients with pulmonary alveolar proteinosis. Am J Respir Crit Care Med 1998;158(4):1294-1298.

142. Tazawa R, Nakata K, Inoue Y, Nukiwa T. Granulocyte-macrophage colony-stimulating factor inhalation therapy for patients with idiopathic pulmonary alveolar proteinosis: a pilot study; and long-term treatment with aerosolized granulocyte-macrophage colony-stimulating factor: a case report. Respirology 2006;11(Suppl):S61-S64.

143. Fujishima T, Honda Y, Shijubo N, Takahashi H, Abe S. Increased carcinoembryonic antigen concentrations in sera and bronchoalveolar lavage fluids of patients with pulmonary alveolar proteinosis. Respiration 1995;62(6):317-321.

144. Minakata Y, Kida Y, Nakanishi H, Nishimoto T, Yukawa S. Change in cytokeratin 19 fragment level according to the severity of pulmonary alveolar proteinosis. Intern Med 2001;40(10):1024-1027.

145. deMello DE, Lin Z. Pulmonary alveolar proteinosis: a review. Pediatr Pathol Mol Med 2001;20(5):413-432.

146. McCook TA, Kirks DR, Merten DF, Osborne DR, Spock A, Pratt PC. Pulmonary alveolar proteinosis in children. AJR 1981;137(5): 1023-1027.

147. Hamvas A, Nogee LM, Mallory GB Jr, Spray TL, Huddleston CB, August A, et al. Lung transplantation for treatment of infants with surfactant protein B deficiency. J Pediatr 1997;130(2):231-239.
148. Huddleston CB, Bloch JB, Sweet SC, de la Morena M, Patterson GA, Mendeloff EN. Lung transplantation in children. Ann Surg 2002;236(3):270-276.

149. Bellon G, Ninet J, Louis D, Jocteur-Monrozier D, Champsaur G. Heart-lung transplantation in a 16-month-old infant. Chest 1992; 102(1):299-300.

150. Numata A, Matsuishi E, Koyanagi K, Saito S, Miyamoto Y, Irie K, et al. Successful therapy with whole-lung lavage and autologous peripheral blood stem cell transplantation for pulmonary alveolar proteinosis complicating acute myelogenous leukemia. Am J Hematol 2006;81(2):107-109.

151. Ramirez J, Campbell GD. Pulmonary alveolar proteinosis: endobronchial treatment. Ann Intern Med 1965;63:429-441.

152. Ramirez J, Schultz RB, Dutton RE. Pulmonary alveolar proteinosis: a new technique and rationale for treatment. Arch Intern Med 1963; 112:419-431.

153. Ramirez J, Kieffer RF Jr, Ball WC Jr. Bronchopulmonary lavage in man. Ann Intern Med 1965;63(5):819-828.

154. Wasserman K, Blank N, Fletcher G. Lung lavage (alveolar washing) in alveolar proteinosis. Am J Med 1968;44(4):611-617.

155. Ramirez J. Pulmonary alveolar proteinosis: treatment by massive bronchopulmonary lavage. Arch Intern Med 1967;119(2):147-156.

156. Zhou B, Zhou HY, Xu PH, Wang HM, Lin XM, Wang XD. Hyperoxygenated solution for improved oxygen supply in patients undergoing lung lavage for pulmonary alveolar proteinosis. Chin Med J (Engl) 2009;122(15):1780-1783.

157. Bingisser R, Kaplan V, Zollinger A, Russi EW. Whole-lung lavage in alveolar proteinosis by a modified lavage technique. Chest 1998; 113(6): 1718-1719.

158. Jansen HM, Zuurmond WW, Roos CM, Schreuder JJ, Bakker DJ. Whole-lung lavage under hyperbaric oxygen conditions for alveolar proteinosis with respiratory failure. Chest 1987;91(6):829-832.

159. Hammon WE, McCaffree DR, Cucchiara AJ. A comparison of manual to mechanical chest percussion for clearance of alveolar material in patients with pulmonary alveolar proteinosis (phospholipidosis). Chest 1993;103(5):1409-1412.

160. Kao D, Wasserman K, Costley D, Benfield JR. Advances in the treatment of pulmonary alveolar proteinosis. Am Rev Respir Dis 1975;111(3):361-363.

161. Perez At, Rogers RM. Enhanced alveolar clearance with chest percussion therapy and positional changes during whole-lung lavage for alveolar proteinosis. Chest 2004;125(6):2351-2356.

162. Harris JO, Castle JR, Swenson EW, Block AJ. Lobar lavage: therapeutic benefit in pulmonary alveolar filling disorders. Chest 1974; 65(6):655-659.

163. Ito T, Sato M, Okubo T, Ono I, Akabane J. Infantile pulmonary alveolar proteinosis with interstitial pneumonia: bilateral simultaneous lung lavage utilizing extracorporeal membrane oxygenation and steroid therapy. Tohoku J Exp Med 1999;187(3):279-283.

164. Freedman AP, Pelias A, Johnston RF, Goel IP, Hakki HI, Oslick T, et al. Alveolar proteinosis lung lavage using partial cardiopulmonary bypass. Thorax 1981;36(7):543-545.

165. Brach BB, Harrell JH, Moser KM. Alveolar proteinosis: lobar lavage by fiberoptic bronchoscopic technique. Chest 1976;69(2):224227.

166. Cheng SL, Chang HT, Lau HP, Lee LN, Yang PC. Pulmonary alveolar proteinosis: treatment by bronchofiberscopic lobar lavage. Chest 2002;122(4):1480-1485.

167. Moutafis M, Dalibon N, Colchen A, Fischler M. Improving oxygenation during bronchopulmonary lavage using nitric oxide inhalation and almitrine infusion. Anesth Analg 1999;89(2):302-304.

168. Nagasaka Y, Takahashi M, Ueshima H, Tohda Y, Nakajima S. Bronchoalveolar lavage with trypsin in pulmonary alveolar proteinosis. Thorax 1996;51(7):769-770. 


\section{Pulmonary Alveolar Proteinosis}

169. Hurrion EM, Pearson GA, Firmin RK. Childhood pulmonary alveolar proteinosis: extracorporeal membrane oxygenation with total cardiopulmonary support during bronchopulmonary lavage. Chest 1994;106(2):638-640.

170. Altose MD, Hicks RE, Edwards MW Jr. Extracorporeal membrane oxygenation during bronchopulmonary lavage. Arch Surg 1976; 111(10):1149-1153.

171. Heymach GJ 3rd, Shaw RC, McDonald JA, Vest JV. Fiberoptic bronchopulmonary lavage for alveolar proteinosis in a patient with only one lung. Chest 1982;81(4):508-510.

172. Nadeau MJ, Cote D, Bussieres JS. The combination of inhaled nitric oxide and pulmonary artery balloon inflation improves oxygenation during whole-lung lavage. Anesth Analg 2004;99(3):676679 .

173. Kavuru MS, Popovich M. Therapeutic whole lung lavage: a stopgap therapy for alveolar proteinosis. Chest 2002;122(4):1123-1124.

174. Bracci L. Role of physical therapy in management of pulmonary alveolar proteinosis: a case report. Phys Ther 1988;68(5):686-689.

175. Hoffman RM, Dauber JH, Rogers RM. Improvement in alveolar macrophage migration after therapeutic whole lung lavage in pulmonary alveolar proteinosis. Am Rev Respir Dis 1989;139(4):10301032.

176. Bury T, Corhay JL, Saint-Remy P, Radermecker M. [Alveolar proteinosis: restoration of the function of the alveolar macrophages after therapeutic lavage]. Rev Mal Respir 1989;6(4):373-375. Article in French.

177. Du Bois RM, McAllister WA, Branthwaite MA. Alveolar proteinosis: diagnosis and treatment over a 10-year period. Thorax 1983; 38(5):360-363.

178. Gale ME, Karlinsky JB, Robins AG. Bronchopulmonary lavage in pulmonary alveolar proteinosis: chest radiograph observations. AJR Am J Roentgenol 1986;146(5):981-985.

179. Ben-Abraham R, Greenfeld A, Rozenman J, Ben-Dov I. Pulmonary alveolar proteinosis: step-by-step perioperative care of whole lung lavage procedure. Heart Lung 2002;31(1):43-49.

180. Rogers RM, Szidon JP, Shelburne J, Neigh JL, Shuman JF, Tantum KR. Hemodynamic response of the pulmonary circulation to bronchopulmonary lavage in man. N Engl J Med 1972;286(23):12301233.

181. Aguinaga MA, Santos P, Renes E, Alvaro PF, Lorente JA, Maudes A, et al. Hemodynamic changes during whole bronchoalveolar lavage in two cases of pulmonary alveolar proteinosis. Intensive Care Med 1991;17(7):421-423.

182. Kavuru MS, Sullivan EJ, Piccin R, Thomassen MJ, Stoller JK. Exogenous granulocyte-macrophage colony-stimulating factor administration for pulmonary alveolar proteinosis. Am J Respir Crit Care Med 2000;161(4 Pt 1):1143-1148.

183. Barraclough RM, Gillies AJ. Pulmonary alveolar proteinosis: a complete response to GM-CSF therapy. Thorax 2001;56(8):664-665.

184. Seymour JF, Presneill JJ, Schoch OD, Downie GH, Moore PE, Doyle IR, et al. Therapeutic efficacy of granulocyte-macrophage colony-stimulating factor in patients with idiopathic acquired alveolar proteinosis. Am J Respir Crit Care Med 2001;163(2):524-531.

185. de Vega MG, Sanchez-Palencia A, Ramirez A, Cervera S, Aneiros J. GM-CSF therapy in pulmonary alveolar proteinosis. Thorax 2002; 57(9):837.
186. Schoch OD, Schanz U, Koller M, Nakata K, Seymour JF, Russi EW, et al. BAL findings in a patient with pulmonary alveolar proteinosis successfully treated with GM-CSF. Thorax 2002;57(3):277-280.

187. Khanjari F, Watier H, Domenech J, Asquier E, Diot P, Nakata K. GM-CSF and proteinosis. Thorax 2003;58(7):645.

188. Venkateshiah SB, Yan TD, Bonfield TL, Thomassen MJ, Meziane M, Czich C, et al. An open-label trial of granulocyte macrophage colony stimulating factor therapy for moderate symptomatic pulmonary alveolar proteinosis. Chest 2006;130(1):227-237.

189. Price A, Manson D, Cutz E, Dell S. Pulmonary alveolar proteinosis associated with anti-GM-CSF antibodies in a child: successful treatment with inhaled GM-CSF. Pediatr Pulmonol 2006;41(4):367-370.

190. Wylam ME, Ten R, Prakash UB, Nadrous HF, Clawson ML, Anderson PM. Aerosol granulocyte-macrophage colony-stimulating factor for pulmonary alveolar proteinosis. Eur Respir J 2006;27(3): 585-593.

191. Yamamoto H, Yamaguchi E, Agata H, Kandatsu N, Komatsu T, Kawai $\mathrm{S}$, et al. A combination therapy of whole lung lavage and GM-CSF inhalation in pulmonary alveolar proteinosis. Pediatr Pulmonol 2008;43(8):828-830.

192. Lieschke GJ, Cebon J, Morstyn G. Characterization of the clinical effects after the first dose of bacterially synthesized recombinant human granulocyte-macrophage colony-stimulating factor. Blood 1989;74(8):2634-2643.

193. Alberti A, Luisetti M, Braschi A, Rodi G, Iotti G, Sella D, et al Bronchoalveolar lavage fluid composition in alveolar proteinosis: early changes after therapeutic lavage. Am J Respir Crit Care Med 1996;154(3 Pt 1):817-820.

194. Luisetti M, Rodi G, Perotti C, Campo I, Mariani F, Pozzi E, et al Plasmapheresis for treatment of pulmonary alveolar proteinosis. Eur Respir J 2009;33(5):1220-1222.

195. Borie R, Debray MP, Laine C, Aubier M, Crestani B. Rituximab therapy in autoimmune pulmonary alveolar proteinosis. Eur Respir J 2009;33(6):1503-1506.

196. Amital A, Dux S, Shitrit D, Shpilberg O, Kramer MR. Therapeutic effectiveness of rituximab in a patient with unresponsive autoimmune pulmonary alveolar proteinosis. Thorax 2010;65(11):1025-1026.

197. Arora PL, Rogers RM, Mayock RL. Alveolar proteinosis: experience with trypsin therapy. Am J Med 1968;44(6):889-899.

198. Brodsky I, Mayock RL. Pulmonary alveolar proteinosis: remission after therapy with trypsin and chymotrypsin N Engl J Med 1961; 265:935-938.

199. Cho K, Nakata K, Ariga T, Okajima S, Matsuda T, Ueda K, et al Successful treatment of congenital pulmonary alveolar proteinosis with intravenous immunoglobulin $\mathrm{G}$ administration. Respirology 2006;11(Suppl):S74-S77.

200. Diaz JP, Manresa Presas F, Benasco C, Guardiola J, Munoz L, Clariana A. Response to surfactant activator (ambroxol) in alveolar proteinosis. Lancet 1984;1(8384):1023.

201. Felts JH. Aerosol enzymatic debridement for pulmonary alveolar proteinosis. N C Med J 1965;26:336-338.

202. Gumpert BC, Nowacki MR, Amundson DE. Pulmonary alveolar lipoproteinosis: remission after antibiotic treatment. West J Med 1994;161(1):66-68.

203. Hashizume T. Pulmonary alveolar proteinosis successfully treated with ambroxol. Intern Med 2002;41(12):1175-1178. 